\title{
Institutional aspects of governance for sustainable development in Flanders
}

\author{
S. Spillemaeckers ${ }^{1} \&$ K. Bachus ${ }^{2}$ \\ ${ }^{1}$ HIVA, Higher Institute of Labour Studies, University of Leuven, Belgium \\ ${ }^{2}$ Member of the Flemish Policy research Centre for Sustainable \\ Development, Belgium
}

\begin{abstract}
Belgium is one of the first countries to integrate the concept of sustainable development in its constitution. One of the reasons for the growing political consciousness is the fact that Belgium, as a small and centrally located country, is following the international political scene closely. In addition, sustainable development is gaining importance on the European and international level.

Even though the country is small, not all government levels are moving at the same pace or in the same way to integrated policymaking, taking into account all aspects of sustainable development. All political levels have their own idea about the manner of implementation.

This paper will focus on the institutional aspects of the Flemish governance model. It describes and analyses how sustainability is currently integrated in the legal framework, in administration, in the political authorities and in the strategic policy framework. It gives an overview of positive evolutions and indicates the bottlenecks.
\end{abstract}

Keywords: sustainable development, governance model, administration for sustainable development, holistic approach, inclusive governance, capacity building, legal framework, Flanders.

\section{Introduction}

This paper will present some of the results of the project of the Flemish Policy research Centre for Sustainable Development on institutional aspects of governance for sustainable development in Flanders, financed by the Flemish 
Government. The research is based on literature and several interviews of Belgian civil servants, experts, politicians, academics and stakeholders.

Belgium is one of the first countries to integrate the concept of sustainable development in its constitution, stipulating that the federal state, the communities and the regions must respect the goals of sustainable development taking into account the social, the environmental and the economic aspects, and intergenerational equity. Political consciousness of the need for a more sustainable government is growing. One of the reasons is the fact that Belgium, as a small and geographically and politically centrally located country, is following closely the international political scene. And sustainable development is gaining importance on the European and international level.

Since 1970, Belgium progressively became a federal State with a Federal Government, three Community governments and three Regional governments. All of these are equal from the legal viewpoint. Each has authority over specific fields. The communities are competent for culture, education, the use of languages and matters relating to the individual as health policy and assistance to individuals. Regions have competences in fields that are connected with their territory such as economy, employment, agriculture, water policy, housing, public works, energy, the environment, town and country planning and foreign trade. The federal government covers the so-called remaining authorities: the government budget (including taxation), the army, the judicial system, social security, foreign affairs and substantial parts of public health and housing.

Not all government levels move at the same pace, nor in the same way to a policy that takes into account all aspects of sustainable development. All political levels have their own idea about the manner of implementation.

In Flanders, the Community and Regional institutions were merged. There is a single Parliament and a single Government, presided by a Minister-president. Each Minister is responsible for at least one of the 13 departments of the administration.

\section{Flemish sustainable development governance}

After the UNCED Conference in 1992, the issue of sustainable development was predominantly taken up by the federal government and administration. In 1997 a law was voted on the way sustainable development should be co-ordinated and implemented on the federal level.

The Flemish government took a later start. Until 2004 most initiatives concerning sustainable development came from the ministry of the environment and from the ministry of foreign affairs. Environmental policy on the Flemish level is well established and planned. Since 1997 the Flemish government approves an Environmental Policy Plan every four years, and each year an Environmental Programme.

Efforts were made to integrate sustainable development in policy fields such as environment, energy, agriculture, economy, transport and innovation policy. A small number of projects involving several departments were initiated on sustainable building and sustainable consumption patterns. However, the number 
of initiatives taken in an interdepartmental way was still limited, and their success strongly depended on the good will of the minister in charge.

After the World Summit for Sustainable Development in Johannesburg (2002) some members of the administration spontaneously created an interdepartmental working group on sustainable development (WGDO). This working group started co-ordinating strategic thinking on the sustainable development policies. They were at the base of the 'Flemish strategy for sustainable development (VSDO)', published in 2006. This is the first official strategy for sustainable development of the Flemish government.

In 2004, sustainable development was explicitly mentioned in the Flemish government declaration and the responsibility for this new domain was given to the Minister-president. At first the focus of the policy was on the development of a Flemish legal framework. Next to the introduction of sustainable development in the Belgian constitutional law a Flemish decree sustainable development was voted in 2008. This decree obliges all departments to report publicly on their sustainable development actions in their annual policy letters.

\section{Legal framework}

Title I, Article 7bis. of the Belgian constitution: "During the exercise of their respective competences the federal state, the communities and the regions will pursue the goals of a sustainable development in its social, economic and environmental aspects, taking into account the intergenerational equity." (own translation).

In April 2007 sustainable development was introduced in the Belgian constitution. The text is concise, but shows the political recognition of sustainable development. Now the application of the principles of sustainable development has become a constitutional obligation for the Flemish government, which can be enforced by the constitutional court. The Flemish ministers and the Flemish government can also be obliged to take into account sustainable development into their decisions by the civil courts and the State Council. Of course, it is not certain yet whether the constitution will de facto be used to prevent Flemish institutions from taking sustainable development for granted. Nevertheless, a first application of article 7bis of the constitution has already taken place. The Antwerp provincial government refused to grant an operating licence for the implantation of an electrical power plant working on palm oil because it is not sustainable. The palm oil would originate from Malaysia and Indonesia where it is the main cause for deforestation.

At the Flemish level a decree for the promotion of sustainable development was approved in 2008 to ensure the continuity of the Flemish governance for sustainable development. It defines sustainable development following the Brundtland definition and formulates the need for transition processes [1].

It defines the Flemish governance for sustainable development as 'inclusive, co-ordinating and participative'. Inclusive governance refers to the fact that each Flemish minister can translate the general sustainable development principles 
agreed upon by the Flemish government in his or her own manner within his or her department. It says policies should lead to maximum synergies in striving towards sustainable development. This is possible by drawing up a transversal line of policy, which is coherent and cross departmental.

Another early task for the newly operating Flemish governance structure was the development of the first official strategy for sustainable development (VSDO). This two-phase strategy was approved in 2006 [2]. The first phase was a vision text written by experts and ministerial cabinets, in consultation with a large number of organisations, such as the association of Flemish cities and municipalities (VVSG) and the association of the Flemish provinces. The second phase, which is still running, will focus on the process and on an action plan.

In the future, each new Flemish government will have to develop a strategy shortly after its inauguration. This strategy has to take into account the evaluation of the previous strategies, social developments, other existing longterm visions and the short-term visions of the coming new government. The strategy must also consider the advices of several social and environmental advisory boards.

\section{Flemish administration for sustainable development}

In a first stage most initiatives for a sustainable development were taken by the environmental department. Some first movers of the administration were able to catch the attention of most of the other administrations, which led to the establishment of the WGDO (supra).

In 2004 sustainable development was recognised as a policy field as such by the Flemish government. The choice was made for an 'inclusive, co-ordinated and participative' governance for sustainable development. It was decided that all horizontal themes with a social implication would be co-ordinated by the department of general governance of the Minister-president. An administrative co-ordination cell for sustainable development was created to co-ordinate all government actions concerning sustainable development and to support the Minister-president. At the same time the interdepartmental working group on sustainable development (WGDO) created after Johannesburg was established officially (see fig.1 Diagram Flemish Institutional Organisation).

\subsection{Minister-president}

\subsubsection{Tasks}

The task of the Minister-president is to harmonise the Flemish policies on sustainable development, watch over the realisation of the objectives, make statements on sustainable development, collaborate with all other government levels and represent Flanders on the international fora. In name of the inclusive policy only a minimal co-ordination can take place, and the departments are expected to take up the most important role. 


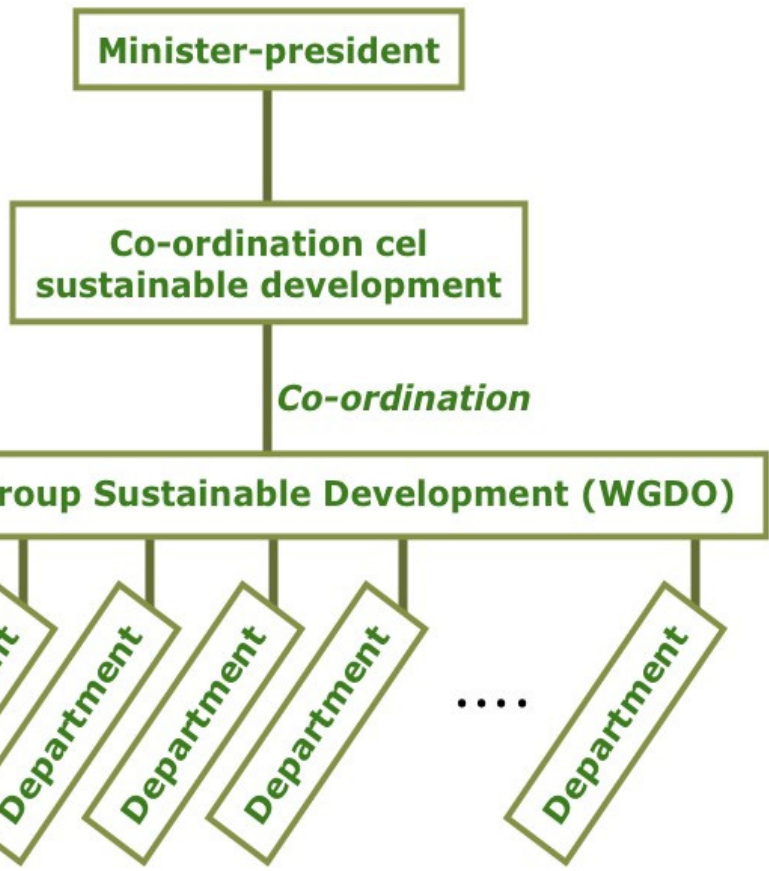

Figure 1: Diagram of Flemish institutional organisation.

\subsubsection{Central co-ordination by Minister-president}

Flanders chose to put sustainable development under the tutorial of the MinisterPresident for many reasons. In the first place international guidelines and internal strategic considerations were taken into consideration.

The OECD [3] considers that governance for sustainable development needs a co-ordinating government structure that stimulates and evaluates sustainable development policies. In criteria III of the Checklist for Sustainable Development of the OECD it is mentioned that 'The need to enforce sustainable development strategies through an overarching institution acting as a 'catalyst' is particularly important, as is the need to ensure mechanisms for critical evaluation'. A later OECD document stipulates that the effectiveness of the implementation of sustainable development is closely related to the placement of overall responsibility at top level, with a preference for the prime minister or president [4].

Bachus et al. [5] showed in a previous study that most stakeholders thought the co-ordination of sustainable development should be attributed to a horizontal department from the Flemish government. It was said that sustainable development is a transversal topic and should as such be present in all departments. Furthermore co-ordination by the Minister-president makes central guidance acceptable. It would be more difficult if a vertical department, like environment or economy, would be in charge of sustainable development coordination. The Minister-president is also associated with political leadership. 
More than other ministers he has the authority to intervene. To assure collaboration between all departments a minister in a strong position is needed. He has to convince all of the necessity to work together in an integrated way. If some of the agreements are not followed, he must be able to intervene.

The position of the Minister-president made it possible to elaborate in quite short notice the legal framework as mentioned above to ensure that sustainable development stays integrated into the Flemish policies, also during next legislations. It obliges departments at least to report on their vision and actions for a sustainable development. It also allowed the WGDO to include all 13 departments in an active way and to make them participate to the elaboration of the action plan of the Flemish strategy.

Although one can conclude from the above that the Minister-President is in the best position to be the co-ordinator of the sustainable development policy, it is not a guarantee for success. An important side condition will have to be met for this model to be successful. Co-ordination by the Minister-president is only efficient if he or she is convinced of the importance of the issue [5]. If this is not the case, it will be given only low priority within the many responsibilities of the head of the government.

At the moment in Flanders sustainable development is not one of the priorities of the Minister-president. His competence of sustainable development is not mentioned on his website and his administration is not encouraged to play an active role in promoting sustainability. Although sustainable development is anchored in the Flemish government, the lack of political priority is felt by the administration and civil society and leads to less involvement in a co-ordinated sustainable development policy.

Another option could be to give the co-ordination to a minister who can spend more time and energy and who is able to take more pronounced positions. For the Minster-president it can be difficult to promote sustainable development because this means he has to take position and has to stand for some values that are not politically neutral. A Minister-president is not always capable to bring up controversial themes and this could lead to a weaker strategy for sustainable development. In principle it should not be necessary to give the competence of sustainable development to the Minister-president, as he does not need this to be able to promote it. In his function he can always support sustainable development, as it is a transversal theme.

\subsubsection{Minimal co-ordination and inclusive policy}

Currently the willingness to further adapt institutional structures for sustainable development in order to make them stronger is lacking. Flanders goes for a minimum co-ordination, a maximal freedom of the departments and a solid legislation in the idea that this should be enough to incite all actors to incorporate sustainable development into their policy. Through the idea of an inclusive policy, the emphasis lies on the fact that the responsibility for the drawing up and the implementation of the sustainable development policies lies with the departments. There is no intention to build out a vast central structure to support the implementation of sustainable development. 
The consequence of this choice for a decentralized governance model with low engagement is that most integrated policy initiatives are not co-ordinated by the sustainable development policy cell, but by thematic departments. Few new initiatives are the result of the current governance model. Till now only few departments developed their own sustainable development policy. Want of political engagement and lack of capacity and knowledge within the departments are some of the main causes.

\subsection{Co-ordination cell for sustainable development}

The co-ordination cell for sustainable development is the administration supporting the Minister-president in the execution of his task as the co-ordinator of sustainable development. First it consisted of two persons. Recently a third staff member was engaged.

Sustainable development is seen as highly political in Flanders, as it touches all departments. Only a minimal intervention of the co-ordinator with existing policies is tolerated. Therefore the administration is closely followed by the political cabinet of the Minister-president. The cabinet takes most of the decisions and develops the strategies and applies the 'primacy of politics'. The cell has to perform operational tasks and is not allowed to take many initiatives. Moreover, it has more assignments than a three person-cell can reasonably execute.

\subsubsection{Tasks}

The most important tasks are the co-ordination of the sustainable development policies and actions and giving the necessary support to the departments; the coordination of the interdepartmental working group for sustainable development; support of the Minister-president; follow-up of the Flemish strategy for sustainable development; administration of the subsidies; cooperation with the federal government, the regions and the communities; representing the Flemish government at all fora in the field of sustainable development; realisation of a Sustainable maturity model (Doma) of the Flemish government and assemble and make accessible existing studies and relevant information on sustainable development [6].

\subsubsection{Co-ordination of actions}

When the Minister-president and his administration got the competence on SD, the idea was that they would co-ordinate all projects concerning sustainable development. In term it was decided otherwise because of shortage of staff. Most current projects on sustainable development involving several departments stay under the control of the former co-ordinating bodies. The argument was brought up that as the projects are going on well there is no need to change this. Departments were also not eager to cede their responsibilities to the new administration. There was a fear that the people who did most of the effort for the projects, would not be the one receiving credit for it.

As a consequence, departments that are committed to sustainable development are still initiating projects on sustainable issues, and are developing 
networks between different departments, but are less and less mentioning the word sustainable development and involving the administration for sustainable development.

Still the administration runs a few important projects such as "criteria for sustainable purchasing management of Flemish governmental organisations" and the Doma, a maturity model for the sustainable development policies in Flanders that was applied to some departments to find out to which degree sustainable development has been structurally embedded in the different administrations.

\subsubsection{Support departments}

Since sustainable development is a relatively new concept and in Flanders, there is still a lack of knowledge on its meaning. Some departments are already working within the concept of sustainable development but not all. For this reason it is necessary that all departments should be informed on sustainable development to find interest in and to build out a sustainable development policy. They should also be provided with the necessary tools and a long-term vision of what the Flemish government aims to achieve. Till now only little capacity building or sensitization is being done as the cell sustainable development is only allowed to support actions of the different departments when explicitly asked for.

\subsubsection{Reporting and respect of agreements}

A summarised reporting is provided based on the documents the different departments hand in on their activities. Most departments deliver this contribution, even if it is sometimes limited and based on actions that are not always done in the aim of attaining a sustainable development. The present indicators for sustainable development are vague and still in development. Monitoring initiatives are scattered. In name of the minimal intervention the SDadministration cannot urge the departments prioritize sustainable development more, or oblige them to observe engagements.

\subsubsection{Co-ordination interdepartmental working group}

The co-ordination cell works together with the interdepartmental working group to guard the coherence of the governance for sustainable development in Flanders. They direct the discussions on different policy items in the working group, and bring information on relevant sustainable development issues.

\subsubsection{Representation in international fora}

Until recently this task was assumed by the environmental department, as they have experience in this matter. They give feedback during the sessions of the interdepartmental working group. Nowadays, the central cell for sustainable development is increasingly taking over the international representation tasks.

\subsection{Working group on sustainable development (WGDO)}

March 2003, after the World Summit on Sustainable Development in Johannesburg, a number of Flemish civil servants informally set up a voluntary interdepartmental working group for sustainable development (WGDO). Here 
discussions were held to adopt common positions at federal, national and international level. It had a temporary recognition and the commitment of the Flemish government. The WGDO managed to get sustainable development on the agenda in Flanders. Two years later the Flemish government decided to institutionalise the working group, and it was enlarged with authorised representatives of all departments. When the co-ordination for cell sustainable development was created they were asked to take up the co-ordination. For the daily management the cell is assisted by representatives of the economic, the social and the environmental departments and the department for foreign affairs.

\subsubsection{Tasks}

The WGDO is meant to be a forum where all departments meet, discuss issues of sustainable development, and exchange knowledge. Through this gathering its objective is a harmonisation of sustainable development policies in Flanders and the cooperation between the different departments.

All administration can thus collaborate in the preparation and evaluation of general sustainable policies. Furthermore the working group prepared the Flemish strategy for sustainable development, is responsible for the relations with the federal and the regional governments, prepared the Flemish positions taken on European and international SD forums and examined the needs of the different departments for information or support.

\subsubsection{Contact persons}

In principle each department implements sustainable development according to its specific culture and possibilities. The members of the working groups are regarded as the contact persons for sustainable development and are supposed to create a network within their own administration. They are responsible for the feedback between the working group and their department.

A large difference occurs between the knowledge level and actions on sustainable development of the different departments. In some departments sustainable development is a regular topic, in others the representative of the working group is not really able to introduce sustainable development into his department by lack of time, support and capacity. Most departments still have a limited political and administrative support on the topic.

The working group is not yet the discussion forum it wants to be. What participants would like are more global discussions on the vision of each department and on how sustainable development can be introduced in the most efficient way in Flanders. It is nevertheless a good place for networking and all departments attend regularly.

\section{Conclusion}

The concept of sustainable development has found its entry in Flemish politics through some enthusiastic first movers and by the pressure of international institutions. The first important impulses were given at the Johannesburg Summit, which encouraged several civil servants to initiate a voluntary interdepartmental working group for a horizontal integration of sustainable 
development. The working group was one of the main motors of the development of the Flemish sustainable development governance. Another strong impulse was given by international regulations and recommendations.

All attention went in the first stage to the development of a legal framework. Since 2007, the Belgian constitution obliges policies to take into account sustainable development and a decree guarantees since 2008 the continuity of the Flemish sustainable development policies. The Flemish strategy for sustainable development was published in 2006, and Belgium is trying to develop a national SD strategy. As a result, other transversal long-term policy projects of the government took up the idea of sustainable development.

According to the policy texts it is important that governance for sustainable development must be co-ordinated and that the policies of all departments must be harmonised. The co-ordination of the Flemish sustainable development policy is done by the Minister-president with the administrative support of the coordination cell sustainable development. The cooperation of all departments is assured through the interdepartmental working group on sustainable development.

In practice only a minimum co-ordination is done because the sustainable development policies may not interfere with existing policies and structures. Policy departments are given maximal freedom and must decide for themselves about how to implement sustainable development into their policy and administration. One of the main reasons invoked for the present slow development of the sustainable development policies of the departments is the fact that almost no adequate capacity building is provided. Civil servants and politicians lack sufficient knowledge of sustainable development to understand its necessity and its challenges. Due to the minimal co-ordination, the low budgets and its limited possibilities of taking initiatives the administration of sustainable development is not yet able to take up this challenge. This is somewhat counterbalanced by the fact that recently, thanks to the influence of the Minister-president, a legislative framework was introduced, obliging departments to implement sustainable development. However, no concrete common goals are defined for Flanders.

In this initial phase this new sector clearly needs a more steering governance structure. The new decree of the Flemish government can be used as a framework for adaptations at the institutional level, as well as regulatory changes, legal embedding and political commitment. New governance structures also require an active strategy to build up relevant networks for sustainable development in association with several social and market actors and the use of innovative policy tools. A balance has to be found between initiatives of the coordinating instance and those of the departments. This could give a new dynamic start for sustainable development in Flanders at all levels.

\section{References}

[1] World Commission on Environment and Development, Our Common Future, From One Earth to One, Report of the UN Documents, World, 1987. A/42/427, http://www.un-documents.net/wced-ocf.htm 
[2] Flemish Government, Strategy for sustainable development, 2006. www2.vlaanderen.be/duurzameontwikkeling/downloads/GrenzenVerleggenLR.pdf (in Dutch)

[3] OECD, Improving policy coherence and integration for sustainable development. A checklist, 2002. www.oecd.org/dataoecd/61/19/2763153.pdf

[4] OECD Sustainable Development Studies, Institutionalising Sustainable Development, OECD publishing, 2007.

[5] Bachus, K., Bruyninckx, H. \& Vandeputte, M., Vlaams structureel overleg voor duurzame ontwikkeling, HIVA, Leuven, 2005; p25 (in Dutch).

[6] Flemish Community, Departement diensten voor het algemeen regeringsbeleid \& PWC, Duurzaamheidsaspecten binnen de werking van de Vlaamse overheid, DOMa, 30 January 2007 (in Dutch). 